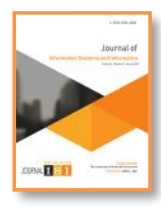

Vol. 1, No. 1, March 2019 e-ISSN: 2656-4882 p-ISSN: 2656-5935

http://journal-isi.org/index.php/isi

Published By DRPM-UBD

\title{
Testing of Technology Acceptance Model on e-Learning based Edmodo Framework: A perspective of Students Perception
}

\author{
Aang Kisnu Darmawan', Nur Umamah² \\ 1, 2Information System Department, Madura Islamic University, Pamekasan, Indonesia \\ Email: ${ }^{1}$ ak.darmawan@gmail.com, ${ }^{2}$ nurrumamahh@gmail.com
}

\begin{abstract}
E-learning is the application of Information and Multimedia Technology in the field of Education which is currently the main trend in the learning process in the classroom. Elearning is currently designed by integrating the learning process using features in social media so as to facilitate the interaction of teachers and students that are expected to improve the efficiency and effectiveness of classroom learning. However, in practice there are still few teachers, educators and students who can apply e-learning well, because they think that the application of e-learning is difficult to implement in classroom learning. Edmodo is one of the most used e-learning framework because of its ease in its application. This study aims to measure the level of student acceptance of the application of Edmodo-based e-learning by using the Technology Acceptance Model (TAM). The method used uses the survey method for 160 upper secondary students. Data analysis was performed using Structural Equation Modeling (SEM) with the help of AMOS 24 software. The results showed that the application of Edmodo-based e-learning had a positive and significant effect on students' motivation and learning outcomes in the classroom.
\end{abstract}

Keywords: e-learning, Edmodo, technology acceptance model

\section{INTRODUCTION}

The application of E-learning is now a guide in the world of education. Elearning is the application of ICT in the field of educational communication which is expected to increase the efficiency and effectiveness of learning in the classroom [1], improve cognitive and motivational abilities [2], character formation and behavior [3] and there is an increase in satisfaction with the learning process [4]. However, in the implementation of e-learning besides being new and not yet widely known [5], not all teachers and students have used elearning[6] and there are still many teachers and students who still feel difficulties in implementing e-learning [7].

Edmodo is a learning framework that used feature social media like Facebook to integrate its to the learning dan teaching process, and its make easier dan

This work is licensed under a Creative Commons Attribution 4.0 International License. 
teaching process more effective, teaching interaction, and assignment [8], Edmodo make student more interactive in blended learning and writing [9][10], motivation student to write [11], motivation to learn science and biology [12], feasible and suitable for teaching in electronics field [13], physical education and sports[14], suitable for teaching process in vocational school [15], and Virtual Class [16].

There are several studies related to measuring the level of student acceptance of the application of e-learning namely Technology Acceptance Model of the Influence of E-Learning Implementation to Students' Motivation [17], Implementation of Technology Acceptance Model to Measure Teacher's Acceptance of Learning Innovations (Case Study of CBR Learning Model at Vocational School [17], Analysis of Technology Acceptance Model in Understanding of Student Behavior Intention in Use of Sikadu [18], Technology Acceptance Model Analysis (TAM) Against the Level of Acceptance of ELearning among Students (Empirical Study at Batam International University and UT-UPBJJ Batam) [19], Analysis of E-Learning User Acceptance Factors in State High Schools in Blitar City Using the Unified Theory of Acceptance and Use of Technology (UTAUT) [6], Application of Technology Acceptance Model to User Acceptance an End of Stmik Stikom Bali E-Learning [20].

Technology Acceptance Model (TAM) is a method for measuring the level of acceptance of students and teachers in the application of technology and elearning [18][17]. This study aims to measure the level of student acceptance of the application of google classroom-based e-learning, using the Framework Technology Acceptance Model. The data analysis technique used is Structural Equation, or Structural Equation Modeling (SEM) using AMOS software version 24. Data is collected by survey method using a Likert scale for 200 Vocational students in the Department of Computer and Network Engineering (TKJ), using stratified random techniques sampling. The contribution of this research is expected to be a consideration by Education stakeholders to use Edmodo-based e-learning in classroom learning.

\section{METHOD}

Observation and data collection was carried out by studying the condition of the object of the research, namely high school then taken as many as 156 high school students for a quantitative survey. The research process is carried out by first applying e-learning in teach high school students to then conduct a quantitative survey using a model in the Framework Technology Acceptance Model (TAM) with a Likert scale. This research was conducted using the following step flow: 


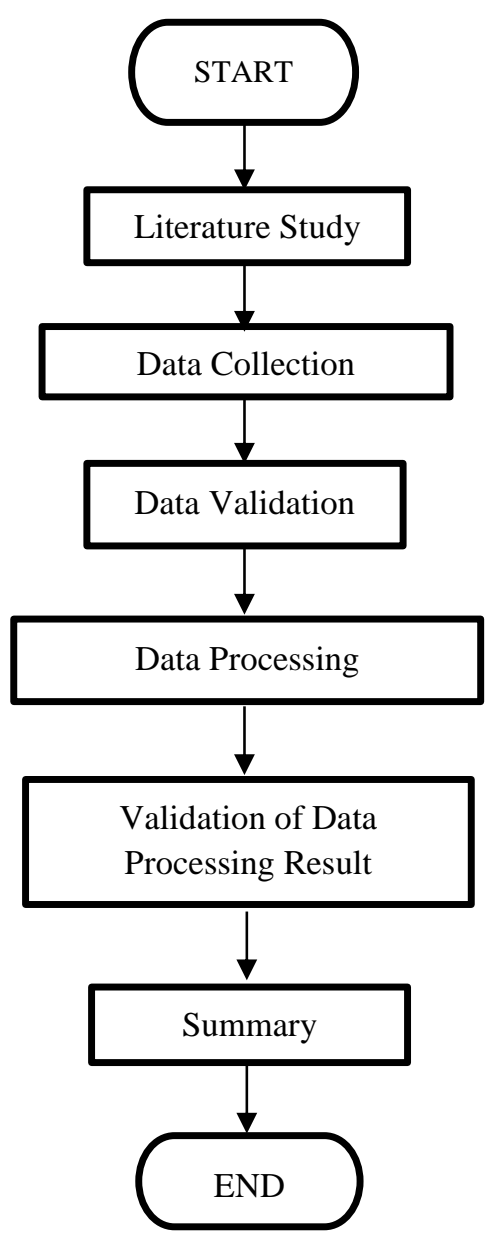

Figure 1: Research Steps

The research starts from the study of literature, namely looking for sources or references related to research both from books, and national journals and international journals. After the source or reference has been studied, data collection is then carried out where data is taken directly to the Senior High School in Pamekasan Regency which will be used as research samples to support the research. The data collected will then be validated and processed using AMOS 24 Software. Then from the results of data processing and analysis, conclusions will be drawn regarding the results of the study. 
Vol. 1, No. 1, March 2019

p-ISSN: 2656-5935 http://journal-isi.org/index.php/isi

e-ISSN: 2656-4882

\section{RESULTS AND DISCUSSION}

\subsection{Testing of CFA and Model Good of Fitness}

The result of measurement testing of confirmatory factor analysis (CFA) was shown as figure below

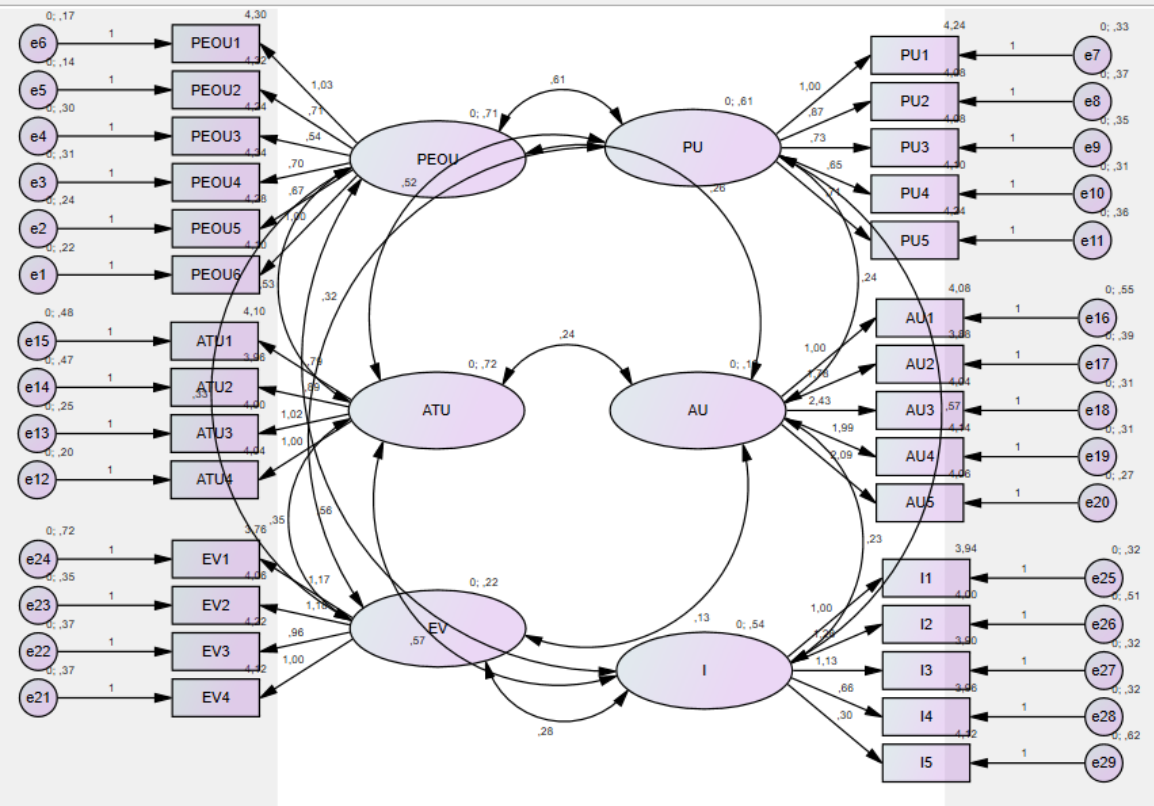

Figure 2. Result of CFA

\subsubsection{Reliability Test}

Done to find out whether in this research model there are unreliable indicator variables. Then the researcher eliminated negative indicators.

\subsubsection{Model Accuracy Test}

In this test the comparative fit index (CFI) value (Baseline Comparisons table in AMOS) and CMIN are used as references. From the results of the tests carried out, the small chi-square value is 1.921 . The RMSEA value is 0,000 , the value of CMIN / DF is 0.208, the value of TLI is 0.554 and the value of CFI is 0.595 . So this states that this research model has a good and usable model index. 


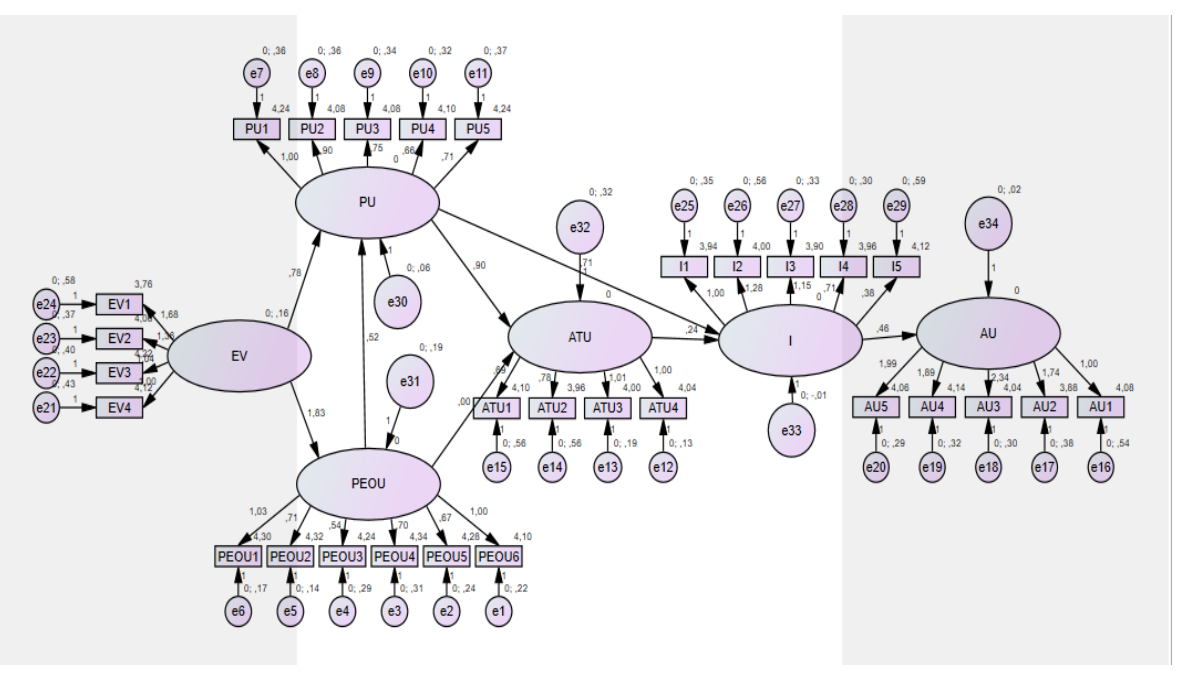

Figure 3. Result of Testing Goodness Fit Model

The hypothesis for the research framework above is as follows:
a) H1: external variables (EV) have a significant effect on perceived ease of use (PEOU)
b) H2: external variables (EV) variables have a significant effect on perceived usefulness (PU)
c) H3: perceived usefulness variable (PU) has a significant effect on perceived ease of use (PEOU)
d) H4: perceived usefulness (PU) variable has a significant effect on attitude towards using (ATU)
e) H5: variables perceived ease of use (PEOU) do not have a significant positive effect on attitude towards using (ATU)
f) H6: perceived usefulness variable (PU) has a significant effect on the behavior of intention to use (I)
g) H7: attitude towards using (ATU) variable has a significant effect on the behavior of intention to use (I)
h) H8: the behavioral variable intention to use (I) has a significant effect on the actual usage (AU)

\subsubsection{Model Interpretation and Modification}

The result of measurement of model fit index was shown as below

Table 1. Measurement of Model Fit Index

\begin{tabular}{cc}
\hline Model Fit Index & Cut Off Value \\
\hline$X^{2-C h i-S q u a r e}$ & Diharapkan kecil \\
Significance Probability & $\geq 0.05$
\end{tabular}




\begin{tabular}{cc} 
p-ISSN: 2656-5935 http://journal-isi.org/index.php/isi & e-ISSN: 2656-4882 \\
\hline RMSEA & $\leq 0.08$ \\
GFI & $\geq 0.80$ \\
AGFI & $\geq 0.80$ \\
CMIN/DF & $\leq 2.00$ \\
TLI & $\geq 0.95$ \\
CFI & $\geq 0.95$
\end{tabular}

The model developed will be interpreted and the model that does not meet the testing requirements is modified. The need for modification can be seen from the number of residuals produced by the model. Modifications need to be considered if the number of residuals is greater than $5 \%$ of all residual covariance generated by the model. If the residual value generated is greater than 2.58 , the way to modify it is to add a new path to the estimated model.

\subsubsection{Test data validity}

Based on the data validity test, it can be explained that there are invalid data because it has a factor load of $<0.5$. As for the test the validity of the data can be seen in the following table below:

Table 2. Indicator Correlation Index

\begin{tabular}{ccc}
\hline Indicator & Correlation Factor & Summary \\
\hline PEOU 1 & 0.815 & Valid \\
PEOU 2 & 0.722 & Valid \\
PEOU 3 & 0.414 & Valid \\
PEOU 4 & 0.532 & Valid \\
PEOU 5 & 0.574 & Valid \\
PEOU 6 & 0.766 & Valid \\
PU1 & 0.621 & Valid \\
PU2 & 0.567 & Valid \\
PU3 & 0.489 & Valid \\
PU4 & 0.444 & Valid \\
PU5 & 0.448 & Valid \\
ATU 1 & 0.403 & Valid \\
ATU2 & 0.460 & Valid \\
ATU3 & 0.811 & Valid \\
ATU4 & 0.860 & Valid
\end{tabular}




\begin{tabular}{ccc} 
p-ISSN: 2656-5935 & http://journal-isi.org/index.php/isi & e-ISSN: 2656-4882 \\
\hline AU1 & 0.199 & Invalid \\
AU2 & 0.514 & Valid \\
AU3 & 0.708 & Valid \\
AU4 & 0.599 & Valid \\
AU5 & 0.647 & Valid \\
EV1 & 0.435 & Valid \\
EV2 & 0.442 & Valid \\
EV3 & 0.299 & Invalid \\
EV4 & 0.268 & Invalid \\
I1 & 0.597 & Valid \\
I2 & 0.602 & Valid \\
I3 & 0.669 & Valid \\
I4 & 0.464 & Valid \\
I5 & 0.112 & Invalid \\
\hline
\end{tabular}

\subsection{Analysis dan Discussion}

The results show that the external variables (EV) have a significant positive relationship to perceived ease of use (PEOU). Because the value of C.R is $1.597>1.96$ which proves that external variables (EV) have a significant positive effect on perceived ease of use (PEOU).

The external variables (EV) variable proved to have a significant positive relationship to perceived usefulness (PU). Because the value of C.R is 1.565> 1.96 which proves that the external variables $(\mathrm{EV})$ variables have a significant effect on the perceived usefulness (PU) variable.

The perceived usefulness (PU) variable is proven to have a significant positive relationship to perceived ease of use (PEOU). Because the value of C.R is $1.732>1.96$ which proves that the perceived usefulness $(\mathrm{PU})$ variable has a significant effect on the variables perceived ease of use (PEOU).

Perceived usefulness variable (PU) proved to have a significant positive relationship to attitude towards using (ATU). Because the C.R value is 1.156> 1.96 which proves that the perceived usefulness (PU) variable has a significant effect on the attitude towards using (ATU) variable.

Variables perceived ease of use (PEOU) proved to have no significant positive relationship to attitude towards using (ATU). Because the value of C.R is 0.115 $<1.96$ which proves that perceived ease of use (PEOU) does not significantly influence the attitude towards using (ATU) variable. 
Perceived usefulness variable (PU) proved to have a significant positive relationship to the behavior intention to use (I). Because the value of C.R is $1.131>1.96$ which proves that perceived usefulness (PU) has a significant effect on the behavioral variable intention to use (I).

The behavioral variable intention to use (I) proved to have a significant positive relationship to the actual usage (AU). Because the value of C.R is 1.827 which proves that the behavioral intention to use (I). Significant effect on the actual usage variable $(\mathrm{AU})$.

\section{CONCLUSION}

Based on analysis had been done we can conclude that External variables (EV) variables have a significant positive relationship to perceived ease of use (PEOU) with the value of C.R is 1.597> 1.96 which means that the hypothesis is accepted, External variables (EV) variables are proven to have a significant positive relationship to perceived usefulness (PU). Because the value of C.R is $1.565>1.96$ which means the hypothesis is accepted, the perceived usefulness (PU) variable is proven to have a significant positive relationship to perceived ease of use (PEOU). Because the value of C.R is $1.732>1.96$ which means that the hypothesis is accepted, the perceived usefulness (PU) variable is proven to have a significant positive relationship to the attitude towards using (ATU). Because the value of C.R is $1.156>1.96$ which means the hypothesis is accepted. Variables perceived ease of use (PEOU) proved to have no significant positive relationship to attitude towards using (ATU). Because the value of C.R is 0.115 $<1.96$ which means the hypothesis is rejected. Perceived usefulness variable (PU) is proven to have a significant positive relationship to the behavioral intention to use (I). Because the value of C.R is 1.131> 1.96 which means the hypothesis is accepted. The behavioral variable intention to use (I) proved to have a significant positive relationship to the actual usage (AU). Because the value of C.R is 1.827, which means that the hypothesis is accepted.

\section{REFERENCES}

[1] M. Fransisca, "Pengujian Validitas, Praktikalitas, dan Efektivitas Media ELearning Di Sekolah Menengah Kejuruan," J. Imiah Pendidik. Tek. Elektro, vol. 2, no. 1, pp. 17-22, 2017.

[2] T. Tigowati, A. Efendi, and C. W. Budiyanto, "The Influence of E-learning Use to Student Cognitive Performance and Motivation in Digital Simulation Course," IJIE (Indonesian J. Informatics Educ., vol. 1, no. 2, pp. 41-48, 2017.

[3] Haryanto, "Kajian Implementasi Pembelajaran Berbasis E-learning dengan Pendekatan Unified Theory of Acceptance and Use of Technology ( UTAUT )," J. Khatulistiva Inform., vol. V, no. 1, pp. 14-20, 2017.

[4] J. T. Otomotif, F. Teknik, and U. N. Padang, "Pengembangan Media 
Pembelajaran Interaktif Pada Sistem E-Learning Universitas Negeri Padang," INVOTEK, vol. 17, no. 2, pp. 1-10, 2017.

[5] N. Asnawi, "Pengukuran Usability Aplikasi Google Classroom Sebagai Elearning Menggunakan USE Questionnaire (Studi Kasus: Prodi Sistem Informasi UNIPMA)," Res. Comput. Inf. Syst. Technol. Manag., vol. 1, no. 1, pp. 17-21, 2018.

[6] D. Destaningrum, Suprapto, and N. H. Wardani, "Analisis Faktor Penerimaan Pengguna E-Learning SMA Negeri di Kota Blitar Menggunakan Model Unified Theory of Acceptance and Use of Technology ( UTAUT )," J. Pengemb. Teknol. Inf. dan Ilmu Komput., vol. 2, no. 2, pp. 723-732, 2018.

[7] C. Dewi, "The Use Of E-Learning As Learning Medium At Secondary Vocational School," J. Innov. Appl. Technol., vol. 3, no. 1, pp. 396-401, 2017.

[8] N. Watoni, F. Trisnawati, and A. Munib, "Indonesian Journal of Curriculum Keefektifan Media Edmodo Sebagai Penunjang Pembelajaran Teknologi Informasi \& Komunikasi di Sekolah Menengah Pertama," Indones. J. Curric. Educ. Technol. Stud., vol. 5, no. 1, pp. 42-48, 2017.

[9] P. Purnawarman, S. Susilawati, and W. Sundayana, "The use of Edmodo in teaching writing in a blended learning setting," Indones. J. Appl. Linguist., vol. 5, no. 2, p. 242, 2016.

[10] S. Sugito and S. E. Mulyani, "The Learning Syntax Through Edmodo in the Beginners Class," Int. J. Eval. Res. Educ., vol. 6, no. 4, pp. 299-305, 2017.

[11] T. Hastomo and S. Pd, "the Effectiveness of Edmodo To Teach Writing Viewed From Students 'Motivation,” ICTTE 2015 Proc., vol. 1, no. Januari, pp. 580-585, 2016.

[12] U. A. Daulay and B. Manurung, "Pengaruh Blended Learning Berbasis Edmodo dan Motivasi Belajar Terhadap Hasil Belajar IPA Biologi dan Retensi Siswa pada Sistem Peredaran Darah Manusia di Kelas VIII SMP Negeri 5 Medan," J. Pendidik. Biol., vol. 6, no. 1, pp. 260-266, 2016.

[13] W. P. Atmanegara, "Pengembangan media pembelajaran elearning menggunakan edmodo pada mata pelajaran elektronika dasar studi pada siswa kelas X TEI SMK Negeri 2 Bojonegoro," J. Pendidik. Tek. Elektro, vol. 5, no. 1, pp. 359-364, 2016.

[14] W. D. Purwaningtyas, "Pengembangan Modul Elektronik Mata Pelajaran Pendidikan Jasmani, Olahraga, Dan Kesehatan Kelas XI Berbasis Online Dengan Program Edmodo," J. Pendidik., vol. 2, no. 1, pp. 121-129, 2017.

[15] D. Kristiani, "E-learning dengan Aplikasi Edmodo di Sekolah Menengah Kejuruan," Pros. Semin. Nas. MULTI DISIPLIN ILMU CALL Pap. UNISBANK KE-2 Tabun 2016 Kaji. Multi Disiplin Ilmu dalam Pengemb. IPTEKS untuk. Mewujudkan Pembang. Nas. Semesta Berencan, pp. 36-45, 2016.

[16] E. Ridhawati, A. Khumadi, J. Wisma, and R. No, "Using Edmodo As A Virtual Class Learning Model In SMK Bakti Utama Merbau Mataram, South Lampung Regency," 3rd Int. Conf. Inf. Technol. Bus., vol. 3, no. 1, pp. 
65-71, 2017.

[17] S. Asiyah, "Indonesian J ournal of I nformatics E ducation Technology Acceptance Model in the Analysis of the Influence of E-Learning Implementation to Students' Motivation," Indones. J. Informatics Educ., vol. 2, no. 1, pp. 55-60, 2018.

[18] R. Widhiastuti and A. Yulianto, “Analysis of Technology Acceptance Model in Understanding of Students Behavior Intention in Use of Sikadu," Din. Pendidik., vol. 12, no. 1, p. 20, 2017.

[19] ibnu harris, "ANALISIS Technology Acceptance Model (Tam) Terhadap Tingkat Penerimaan E-Learning Pada Kalangan Mahasiswa (Studi Empiris pada Universitas Internasional Batam dan UPBJJ-UT Batam)," J. Terap. Manaj. dan Bisnis, vol. 3, no. 1, pp. 1-20, 2017.

[20] N. M. Shandyastini, K. Dwi, and P. Novianti, "PENERAPAN TECHNOLOGY ACCEPTANCE MODEL TERHADAP PENERIMAAN PENGGUNA AKHIR E-LEARNING STMIK STIKOM BALI Program Studi Sistem Komputer, STMIK STIKOM Bali email : shandyastini311090@yahoo.co.id Program Studi Sistem Informasi, STMIK STIKOM Bali email : novia," J. Teknol. Inf., vol. 8, no. 1, pp. 41-48, 2017. 